$6-21-2020$

\title{
Ecological Associations of Littoraria irrorata with Spartina cynosuroides and Spartina alterniflora
}

\author{
Caroline Mackenzie Failon \\ Virginia Institute of Marine Science \\ Serina Sebilian Wittyngham \\ Virginia Institute of Marine Science \\ David S. Johnson \\ Virginia Institute of Marine Science
}

Follow this and additional works at: https://scholarworks.wm.edu/vimsarticles

Part of the Marine Biology Commons, and the Terrestrial and Aquatic Ecology Commons

\section{Recommended Citation}

Failon, Caroline Mackenzie; Wittyngham, Serina Sebilian; and Johnson, David S., Ecological Associations of Littoraria irrorata with Spartina cynosuroides and Spartina alterniflora (2020). Wetlands. doi: 10.1007/s13157-020-01306-4

This Article is brought to you for free and open access by the Virginia Institute of Marine Science at W\&M ScholarWorks. It has been accepted for inclusion in VIMS Articles by an authorized administrator of W\&M ScholarWorks. For more information, please contact scholarworks@wm.edu. 
Ecological associations of Littoraria irrorata with Spartina cynosuroides and

Spartina alterniflora

Caroline Mackenzie Failon*1, Serina Sebilian Wittyngham ${ }^{1}$, and David Samuel Johnson ${ }^{1}$

$4{ }^{1}$ Virginia Institute of Marine Science, William \& Mary, P.O. Box 1346, Gloucester Point, VA,

5 23062, USA

$6 \quad *$ Corresponding author: caroline.mackenzie.failon@gmail.com, (804) 684-7148

\section{Abstract}

8 It is well-documented that marsh periwinkles (Littoraria irrorata) consume and inhabit smooth 9 cordgrass (Spartina alterniflora), but their interactions with big cordgrass (Spartina

10 cynosuroides) remain unknown. Plant communities in mesohaline marshes will change as sea11 level rise shifts species from salt-intolerant (e.g., S. cynosuroides) plants to salt-tolerant (e.g., S. 12 alterniflora) ones. Therefore, understanding how L. irrorata interacts with different habitats 13 provides insight into this species' generalist nature and allows us to predict the potential impacts 14 of changing plant communities on L. irrorata. We show, for the first time, that L. irrorata 15 inhabits, climbs, and grazes $S$. cynosuroides. We compared both habitats and found snails were larger, plant tissue was tougher, and sediment surface temperatures were higher in S. alterniflora than $S$. cynosuroides. Snails had greater survivorship from predators in S. cynosuroides than in $S$. alterniflora. Further, snails grazed $S$. cynosuroides more than S. alterniflora, evidenced by a greater number of radulation scars. Despite these differences, snail densities were equal between habitats suggesting functional redundancy between $S$. cynosuroides and S. alterniflora for $L$. irrorata. Our results indicate L. irrorata is a habitat generalist that uses both S. alterniflora and $S$. cynosuroides, which may allow it to gain an ecological foothold as sea-level rises.

Keywords: brackish marsh, mesohaline marsh, salt marsh, ecological equivalence, sea level rise 


\section{Introduction}

35 Tidal marshes cover approximately 45,000 $\mathrm{km}^{2}$ globally (Greenberg et al. 2006) and contribute

36 ecologically and economically to human well-being by providing erosion and flood control,

37 recreation, improved water quality, carbon sequestration, and nursery habitat for commercially

38 important fishes and invertebrates (Boesch et al. 2000; Beck et al. 2001; Shepard et al. 2011).

39 There are $16,000 \mathrm{~km}^{2}$ of tidal marshes in North America alone, with high concentrations on the

40 South Atlantic coast and Gulf of Mexico (Greenberg et al. 2006). The Chesapeake Bay in the

41 United States contains an estimated 1,240 $\mathrm{km}^{2}$ of tidal marshes, with brackish marshes making

42 up one-third of this area (Stevenson et al. 2000). A mesohaline marsh is a type of estuarine

43 brackish marsh where saline and fresh waters mix, leading to salinities between 5 and 18 ppt on

44 average (Odum 1988). Despite their abundance, mesohaline marshes are relatively understudied

45 compared to their polyhaline counterparts (i.e., salt marshes, $18-30 \mathrm{ppt}$ ), especially regarding

46 their flora and fauna.

Mesohaline marshes tend to have higher plant diversity than that of polyhaline marshes

48 (Odum 1988) because a greater abundance of vascular plant species can tolerate lower salinities

49 (Anderson et al. 1968; Wass and Wright 1969; Perry and Atkinson 1997). On the Atlantic coast

50 of the United States, the lowest elevations of mesohaline marshes are dominated by two co-

51 occuring species: the smooth cordgrass, Spartina alterniflora, and the big cordgrass, Spartina

52 cynosuroides. Both species have similar growth forms, with leaves growing from a single tall

53 stem (culm) and rhizamatous belowground biomass (Silberhorn 1992; McHugh and Dighton

54 2004). However, in the Chesapeake Bay region, S. cynosuroides ranges from 2 to 4 meters tall,

55 whereas S. alterniflora ranges from 1 to 2 meters tall (Silberhorn 1992). Both species are flood

56 tolerant, however S. alterniflora has a wider salt tolerance than S. cynosuroides (Penfound and 
57 Hathaway 1938). Spartina alterniflora commonly dominates polyhaline marsh communities due

58 to its ability to outcompete salt-sensitive species, however it can also thrive in lower salinity

59 marshes (Stribling 1997; White and Alber 2009). In contrast, S. cynosuroides prefers oligohaline

60 (0.5-5 ppt) environments but can tolerate freshwater to mesohaline conditions (Odum et al. 1984;

61 Constantin et al. 2019). The co-occurrence of these plant species creates distinct habitat types

62 with qualities that may attract similar fauna to each.

63 The marsh periwinkle (Littoraria irrorata) is an abundant and herbivorous gastropod

64 found in tidal marshes along the Gulf of Mexico and Atlantic coast of the United States. It

65 thrives in salinities ranging from 5 to $30 \mathrm{ppt}$; however, it can survive shorter periods of time (less

66 than a week) in salinities from 0 to 5 ppt (Crist and Banta 1983; Henry et al. 1993). It is a critical

67 component of saltmarsh food webs (McCann et al. 2017) as prey for fishes and crustaceans

68 (Hamilton 1976) and as a consumer of live and dead S. alterniflora, marsh sediment, algae,

69 diatoms, nematodes, foraminifera, ostracods, mites, copepods, and other microorganisms

70 (Alexander 1979). Littoraria irrorata climbs plant stems to avoid rising tides and aquatic

71 predators (Warren 1985; Carroll et al. 2018), as well as to cultivate fungus colonies on plant

72 leaves for consumption (Silliman and Zieman 2001; Silliman and Newell 2003). At

73 extraordinarily high densities, this fungal farming by L. irrorata can lower aboveground biomass

74 of S. alterniflora (Silliman and Zieman 2001). During low tide, some snails move back to the

75 sediment surface to feed and to avoid the threat of desiccation (Bingham 1972).

$76 \quad$ Littoraria irrorata is frequently studied in polyhaline marshes and therefore associated

77 primarily with S. alterniflora (e.g., Hamilton 1976; Silliman and Zieman 2001; Silliman and

78 Newell 2003; Deis et al. 2017; Zengel et al. 2017; Rietl et al. 2018). In the mesohaline marshes

79 of the Chesapeake Bay, we have observed L. irrorata in both S. alterniflora and S. cynosuroides 
80 habitats. Here, we document, for the first time to our knowledge, the ecological use of $S$.

81 cynosuroides by L. irrorata in a mesohaline marsh. Our goals were to compare the

82 environmental characteristics, predation pressure, palatability of plant tissue, and algal-food

83 availability between $S$. alterniflora and S. cynosuroides habitats in relation to L. irrorata use. We

84 expected that L. irrorata climbed S. cynosuroides to avoid predation, similar to its behavior in $S$.

85 alterniflora. However, we hypothesized that S. alterniflora was more palatable than S.

86 cynosuroides, as the use of S. alterniflora as a preferred food source for L. irrorata is well-

87 documented (e.g. Hendricks et al. 2011; Sieg et al. 2013). We also expected the difference in

88 plant height between S. alterniflora and S. cynosuroides to influence the foraging behavior of $L$.

89 irrorata. For example, taller S. cynosuroides may limit access to leaves or light penetration to the

90 substrate, thus decreasing benthic diatom growth, an additional food for L. irrorata (Alexander

91 1979).

92

93 Methods

94 Study Site

95 Our study focused on the mesohaline marsh surrounding Taskinas Creek (37²4' $54.79 " \mathrm{~N} ; 7^{\circ}$

96 42' 52.74" W; Fig. 1), within the Chesapeake Bay watershed in James City County, Virginia,

97 USA. Access to this York River State Park site was possible through the Chesapeake Bay

98 National Estuarine Research Reserve of Virginia (CBNERR-VA), which maintains marsh

99 monitoring stations within the York River estuary. Taskinas Creek has an average salinity of 6 to

1007 ppt (VECOS Database, accessed: July 16, 2019) with a semidiurnal tidal range of $0.85 \mathrm{~m}$ on

101 average. The low marsh exists below the mean high-water level and is dominated by distinct,

102 side-by-side, monotypic stands of S. alterniflora and S. cynosuroides, with L. irrorata found in 
103 both habitats. The high marsh above the mean high-water level is made up of mostly salt hay

104 (Spartina patens) and saltgrass (Distichlis spicata).

105

106 Snail \& Environmental Data

107 We established two, 20-meter transects one meter from the creek bank, one in a monotypic stand 108 of S. alterniflora, and the other in a monotypic stand of S. cynosuroides. Along each transect, we 109 haphazardly placed twenty $0.0625 \mathrm{~m}^{2}$ quadrats (total of forty quadrats) to estimate stem heights

110 and densities. Plant height was measured for all live plants within quadrats and the tallest plant

111 from each quadrat was clipped from the base and stored in a $-80^{\circ} \mathrm{C}$ freezer to await plant trait

112 analysis. The second tallest plant from each quadrat was clipped from the base and processed

113 with a penetrometer immediately for tissue toughness (see below). To evaluate $L$. irrorata

114 densities in S. alterniflora and S. cynosuroides, thirty $0.0625 \mathrm{~m}^{2}$ quadrats per habitat (total of

115 sixty quadrats) were haphazardly sampled and all snails within each quadrat were counted. In a

116 separate sampling effort, adult snails were haphazardly collected along each transect within each

117 habitat (S. alterniflora, $\mathrm{n}=184$; S. cynosuroides, $\mathrm{n}=128$ ) and measured in the lab for height and

118 width using digital calipers to determine average snail size. Height was measured from the tip of

119 the shell spire to the bottom of the shell aperture. Width was measured diagonally from the

120 widest part of the shell aperture to the body whorl. To assess leaf damage from snail grazing,

121 fifteen $0.0625 \mathrm{~m}^{2}$ quadrats were haphazardly placed within each habitat type. In each quadrat,

122 five plants were chosen at random to measure heights and to count radulations. In addition, four

123 Onset HOBO pendants were deployed from July $11^{\text {th }}$ to August $6^{\text {th }}$, 2018 to measure light

124 intensity and temperature in S. alterniflora and S. cynosuroides habitats, with two pendants per

125 habitat. To estimate benthic algal biomass, a benthic chlorophyll $a$ sample was taken to a depth 
126 of $3 \mathrm{~mm}$ from the sediment surface (volume $=0.29 \mathrm{~mL}$ ) and placed in a cooler of ice. The

127 samples were then stored in a $-80^{\circ} \mathrm{C}$ freezer to await further processing. Chlorophyll $a$ was

128 extracted in $10 \mathrm{~mL}$ of $90 \%$ acetone for 24 hours and filtered through a $0.45 \mu \mathrm{m}$ Acrodisc with

129 absorbance measured at 630, 647, 664, 665, and $750 \mathrm{~nm}$ against a 90\% acetone blank (Brush MJ,

130 personal communication). An additional acidification step allowed for phaeophytin correction.

131 Chlorophyll $a$ concentration was calculated using the following equation where V is the volume

132 of extractant in $\mathrm{mL}(10 \mathrm{~mL})$, SA is the core area in $\mathrm{cm}^{2}\left(0.95 \mathrm{~cm}^{2}\right)$, and $\mathrm{L}$ is the light path length

133 in cm (1 cm, UV-1601 Shimadzu UV Visible) (Lorenzen 1967; Jeffrey and Welschmeyer 1997).

$$
\operatorname{Chl}_{\mathrm{a}}\left(\mathrm{mg} \cdot \mathrm{m}^{-2}\right)=\frac{26.7 \times\left(\lambda 665-\lambda 665_{\mathrm{acid}}\right)}{(\mathrm{L})} \times \frac{\mathrm{V}}{\mathrm{SA}} \times \frac{1 \mathrm{mg}}{1000 \mu \mathrm{g}} \times \frac{10000 \mathrm{~cm}^{2}}{1 \mathrm{~m}^{2}}
$$

136 Predation Assays

137 To examine predation pressure between the two habitats and the effect of distance from the creek

138 bank, three predation trials were conducted on successive tides. Each trial consisted of tethers in

139 both habitats positioned $1 \mathrm{~m}, 2 \mathrm{~m}$, and $3 \mathrm{~m}$ from the creek. Each tether consisted of one adult

140 snail attached with super glue to a $15 \mathrm{~cm}$ segment of $1.8 \mathrm{~kg}$ monofilament fishing line tied to a

$14130 \mathrm{~cm}$ clear plastic rod. For each distance from the creek bank, 8 snails were tethered and

142 separated by at least $0.5 \mathrm{~m}$ from each other for a total of 24 snails per habitat. This design

143 allowed us to assess predation pressure in relation to distance from the creek, as predators of $L$.

144 irrorata arrive with the incoming tide. Within the vegetated habitats, each rod was placed near a

145 single plant stem and pushed into the sediment until the tether and snail were flush with the

146 sediment surface. The tether was long enough to allow snails to climb the adjacent plant stem to

147 avoid predation, but short enough that they could not get tangled with any other nearby

148 vegetation. The tethers were deployed at low tide and were retrieved after 24 hours. 
$150 \quad$ Plant Traits

151 To determine tissue toughness of fresh leaves, we used a penetrometer consisting of an insect pin

152 attached to a plastic tray which was suspended above leaf material (Pennings et al.1998; Siska et

153 al. 2002). A plastic cup was placed on the tray and dry sand was added to the cup until the pin

154 pierced the tissue. The mass of sand in kilograms required to pierce the tissue was indicative of

155 leaf toughness. This was then converted into a measure of force in newtons (N). Toughness was

156 assessed for each leaf and an average was determined for each plant. Frozen plants were freeze

157 dried in a Labconco Freezone system for 72 hours. Dry mass was recorded, and plants were

158 ground to a fine powder using a mini Wiley mill fitted with a 40-mesh sieve. Total soluble

159 protein content was measured using a modified Bradford assay with absorbance read at $595 \mathrm{~nm}$

160 and compared to a Bovine Serum Albumin (BSA) standard curve. Total phenolic concentrations

161 were determined using a modified Folin-Ciocalteu assay with absorbance measured at $760 \mathrm{~nm}$

162 and compared to a ferulic acid standard curve. Carbon [C] and Nitrogen [N] content were

163 analyzed using a Fisher Scientific FlashEA system.

164

165 Statistical Analysis

166 All statistical analyses were conducted using R software (Version 3.5.1, R Core Team, 2018).

167 The response variables snail height and width, C:N, \%N, tissue toughness, benthic chlorophyll $a$,

168 temperature, and light intensity were analyzed using one-way ANOVAs with habitat type as the

169 factor, while protein content and phenolic concentration were analyzed with ANCOVA, with

170 plant biomass serving as the covariate. For all responses the assumptions of normality and

171 homogeneity of variance were tested; if data did not meet these assumptions, responses were 
172 transformed via Box-Cox transformations. For ANCOVA, the assumptions of linearity and

173 equality of slopes were also tested. If there was no relationship between the response and the

174 covariate, the covariate was removed from the model. Predation data was analyzed with a

175 binomial logistic regression, while generalized linear models with a negative binomial

176 distribution were used for radulations and snail count data. To account for differences in size

177 between S. alterniflora and S. cynosuroides, the covariate, plant height, was included in the 178 analysis of radulation data.

179

180 Results

181 Snail \& Environmental Data

182 Habitat type had no significant effect on snail density $(\mathrm{p}=0.43)$, with an average of $42.15 \pm 8.15$

183 standard error (se) snails per $\mathrm{m}^{2}$ across habitats. However, habitat type did influence snail height 184 ( $\mathrm{p}<<0.01 ;$ S. alterniflora, mean=19.27 \pm 0.15 se; S. cynosuroides, mean $=18.40 \pm 0.10$ se) and

185 width ( $<<<0.01 ;$ S. alterniflora, mean=14.94 \pm 0.11 se; $S$. cynosuroides, mean=14.35 \pm 0.08 se),

186 with larger snails found in S. alterniflora. One snail from S. alterniflora habitat was excluded

187 from analysis as an outlier due to small size. There was a wider distribution of both heights and

188 widths in S. alterniflora than S. cynosuroides (Online Resource 1). Habitat type also had a

189 significant effect on the number of radulations ( $\mathrm{p}=0.05$, Fig. 2), with more found on $S$.

190 cynosuroides than on S. alterniflora. There was no significant effect of the covariate, plant

191 height, on the number of radulations $(\mathrm{p}=0.84)$. Additionally, habitat type had a significant effect

192 on daily temperature ( $\mathrm{p}=0.03$, Online Resource $2 \mathrm{a}$ ), with higher temperatures in S. alterniflora

193 (Online Resource 2a), but no significant effect on daily light intensity ( $\mathrm{p}=0.86$, Online Resource 
194 2b). Benthic chlorophyll $a$ was similar between habitats ( $=0.69)$, for a combined mean of

$19536.19 \pm 4.07 \mathrm{se} \mathrm{mg} / \mathrm{m}^{2}$.

Predation Assays

198 Trial number had no significant effect on survival $(\mathrm{p}=0.67)$, therefore data from each trial was 199 pooled. We found that habitat type ( $\mathrm{p}=0.02$, Fig. 3a) had a significant effect on survival, with 200 greater survival in S. cynosuroides than in S. alterniflora. In addition, distance from the creek 201 also had a significant effect on survival ( $\mathrm{p}=0.01$, Fig. 3b), with the highest survival farthest from 202 the creek (3 m away), and the lowest survival closest to the creek (1 m away).

Plant Traits

205 Plant type had a significant effect on both tissue toughness ( $\mathrm{p}<<0.01$, Fig. 4a) and total soluble 206 protein content ( $\mathrm{p}<0.01$, Fig. 4b), with the covariate, biomass, having no significant effect on

207 protein content ( $\mathrm{p}=0.41$ ). Spartina cynosuroides had higher protein content while S. alterniflora 208 tissues were tougher. In addition, plant type had no significant effect on either $\% \mathrm{~N}(\mathrm{p}=0.32 ; S$.

209 alterniflora, mean $=0.89 \pm 0.03$ se; S. cynosuroides, mean $=0.94 \pm 0.04$ se) or C:N molar ratio 210 ( $\mathrm{p}=0.59 ;$ S. alterniflora, mean=54.25 \pm 2.00 se; S. cynosuroides, mean=52.56 \pm 2.33 se). Plant 211 type and biomass had a significant interactive effect on total phenolic concentration ( $\mathrm{p}=0.03$, Fig. 212 5). Due to this significant interaction, main effects were not explored further.

\section{Discussion}

We demonstrate, for the first time to our knowledge, that $L$. irrorata will use $S$. 
217 significant differences in the size of $L$. irrorata, environmental characteristics, predation

218 pressure, and palatability of plant tissue. In S. alterniflora habitat, we found significantly larger

219 snail height and width, higher daily surface temperatures, and tougher plant tissues. In S.

220 cynosuroides habitat, we found significantly higher plant protein content, safer habitat from

221 predation, and a higher number of radulations. Despite these differences, snails were seen

222 climbing the stems of both S. alterniflora and S. cynosuroides at high tide and densities were

223 equal between habitats. This suggests that, from a population level, snails use both habitats

224 similarly. Thus, from the perspective of L. irrorata, S. cynosuroides and S. alterniflora habitats

225 may be functionally redundant. Research is needed in additional marshes to confirm these

226 results, as this study was conducted in a single marsh.

227 Predation pressure on L. irrorata was higher in S. alterniflora than in S. cynosuroides,

228 indicating that S. cynosuroides serves as better predation refuge for snails. One possible

229 explanation for this trend is plant size. Spartina cynosuroides is much larger, in terms of biomass

230 and height, than S. alterniflora and potentially provides more structure to impede incoming

231 predators of $L$. irrorata, such as the blue crab (Callinectes sapidus), during tidal flooding.

232 Although we found greater survivorship in S. cynosuroides than in S. alterniflora, snail densities

233 did not differ between the habitats, suggesting that there is limited predator control of snail

234 populations or that the effects of predation are ultimately offset by recruitment. While L irrorata

235 larvae settle over wide portions of the marsh, they do not move far from their settlement site over

236 the course of their life (Hamilton 1978; Vaughn and Fisher 1992). Distance from the creek

237 enhanced L. irrorata survival in both habitats, likely because plant shoots impede benthic

238 predators such as crabs (Schindler et al. 1994; Lewis and Eby 2002). This indicates that snails

239 are most susceptible to predators at the edge and that the interior provides a predation refuge, a 
240 trend seen for L. irrorata in mixed marshes of J. roemarianus and S. alterniflora (Hughes 2012)

241 and for other mollusks in tidal marshes (ribbed mussels, Geukensia demissa, Lin 1989, coffee-

242 bean snails, Melampus bidentatus, Johnson and Williams 2017).

243 We found that benthic chlorophyll $a$ concentration was similar between the two habitats,

244 which means that each habitat could provide comparable levels of algae for $L$. irrorata to

245 consume. Although it is well-documented that L. irrorata will graze and fungal farm on $S$.

246 alterniflora (Vaughn and Fisher 1992; Silliman and Zieman 2001), we found that they will also

247 graze S. cynosuroides, as it had more radulations than S. alterniflora. In our study, S.

248 cynosuroides had higher forage quality than S. alterniflora, as indicated by weaker tissues and

249 higher protein content. Further, S. alterniflora produces Dimethylsulphoniopropionate (DMSP),

250 a known deterrent to herbivores, whereas S. cynosuroides does not (Otte et al. 2004). The lack of

251 DMSP production and higher forage quality of S. cynosuroides may be responsible for

252 promoting more grazing on S. cynosuroides. Despite our finding that L. irrorata grazes more on

253 S. cynosuroides than S. alterniflora, L. irrorata is a generalist feeder (Alexander 1979) and both

254 plants may ultimately serve as a source of food for $L$. irrorata.

255 Our work contributes to the evidence that L. irrorata is a habitat generalist that will use

256 marsh vegetation other than S. alterniflora as habitat (Lee and Silliman 2006; Hendricks et al.

257 2011; Hughes 2012; Sieg et al. 2013; Kicklighter et al. 2018). For instance, L. irrorata will use

258 Juncus roemarianus as a refuge from predation over S. alterniflora in mixed-species marshes

259 (Hughes 2012), however it remains unknown whether J. roemarianus can also serve as a food

260 source. Littoraria irrorata prefers to inhabit and consume S. alterniflora over Phragmites

261 australis, Bolboschoenus robustus (Kicklighter et al. 2018), Batis maritima, Borrichia

262 frutescens, Sarcocornia sp., and Iva frutescens (Sieg et al. 2013), due to its low chemical defense 
263 and greater palatability (Hendricks et al. 2011; Sieg et al. 2013; Kicklighter et al. 2018). Further,

264 both $P$. australis and B. robustus were better at inhibiting fungal growth than S. alterniflora,

265 leading to a greater density of L. irrorata on S. alterniflora stems than these other species

266 (Kicklighter et al. 2018).

267 Our results have implications for periwinkles adjusting to changing plant communities in

268 mesohaline marshes due to sea-level rise. Mesohaline marsh vegetation is resilient to acute

269 pulses of salinity from spatial and temporal changes in tidal salinity gradients (Jarrell et al. 2016;

270 Li and Pennings 2018), however, chronic saline presses from sea-level rise could result in a shift

271 in plant communities in mesohaline marshes from salt-intolerant (e.g., S. cynosuroides) to salt-

272 tolerant plant species (e.g., S. alterniflora). In marshes where S. cynosuroides and S. alterniflora

273 co-occur, this disparity in salt tolerance could lead to monotypic stands of S. alterniflora, as salt-

274 water intrusion via sea-level rise drives salinity above the threshold for S. cynosuroides. Our

275 results suggest that $L$. irrorata is a habitat generalist, one that will use both S. alterniflora and $S$.

276 cynosuroides as functionally redundant habitats, which may allow it to gain an ecological

277 foothold in brackish marshes as sea-level rises.

278

279 Acknowledgements

280 We thank the following people for help in the field and laboratory: Manisha Pant, Catherine

281 Wilhelm, Kayla Martínez-Soto, Emily Goetz, Anna Ledwin, Leah Scott, Mark Brush, and Sarah

282 Blachman. Many thanks go to the Chesapeake Bay National Estuarine Research Reserve of

283 Virginia (CBNERR-VA) and York River State Park for access to our study site, Taskinas Creek.

284 We are thankful to the Virginia Institute of Marine Science for funding this project. This work

285 was funded, in part, by the National Science Foundation (grant number 1832221) and the 
Virginia Institute of Marine Science. This paper is Contribution No. 3899 of the Virginia

287 Institute of Marine Science, William \& Mary. Lastly, we thank the snails for their persistent efforts to escape.

\section{References}

Alexander SK (1979) Diet of the periwinkle Littorina irrorata in a Louisiana salt marsh. Gulf Research Reports 6:293-295.

Anderson RR, Brown RG, Rappleye RD (1968) Water quality and plant distribution along the Upper Patuxent River, Maryland. Chesapeake Science 9:145-156.

Beck MW, Heck KL Jr, Able KW, Childers DL, Eggleston DB, Gillanders BM, Halpern B, Hays CG, Hoshino K, Minello TJ, Orth RJ, Sheridan PF, Weinstein MP (2001) The identification, conservation, and management of estuarine and marine nurseries for fish and invertebrates. BioScience 51:633-641.

Bingham FO (1972) The influence of environmental stimuli on the direction of movement of the supralittoral gastropod Littorina irrorata. Bulletin of Marine Science 22:309-335.

Boesch DF, Field JC, Scavia D (eds) (2000) The potential consequences of climate variability and change on coastal areas and marine resources: report of the coastal areas and marine resources sector team, U.S. national assessment of the potential consequences of climate variability and change, U.S. Global Change Research Program. NOAA Coastal Ocean Program Decision Analysis Series No. 21. NOAA Coastal Ocean Program, Silver Spring, MD. 163 pp.

Carroll JM, Church MB, Finelli CM (2018) Periwinkle climbing response to water- and airborne predator chemical cues may depend on home-marsh geography. PeerJ 6:e5744.

Constantin AJ, Broussard III WP, Cherry JA (2019) Environmental gradients and overlapping ranges of dominant coastal wetland plants in Weeks Bay, AL. Southeastern Naturalist 18:224-239.

Crist RW, Banta WC (1983) Distribution of marsh periwinkle Littorina irrorata (Say) in a Virginia salt marsh. Gulf Research Reports 7:225-235.

Deis D, Fleeger JW, Bourgoin SM, Mendelssohn IA, Lin Q, Hou A (2017) Shoreline oiling effects and recovery of salt marsh macroinvertebrates from the Deepwater Horizon oil spill. PeerJ 5:e3680. 
Greenberg R, Maldonado JE, Droege S, McDonald MV (2006) Tidal marshes: a global perspective on the evolution and conservation of their terrestrial vertebrates. BioScience 56:675-685.

Hamilton PV (1976) Predation on Littorina irrorata (Mollusca:Gastropoda) by Callinectes sapidus (Crustacea:Portunidae). Bulletin of Marine Science 26:403-409.

Hamilton PV (1978) Intertidal distribution and long-term movements of Littorina irrorata (Mollusca: Gastropoda). Marine Biology 46:49-58.

Hendricks LG, Mossop HE, Kicklighter CE (2011) Palatability and chemical defense of Phragmites australis to the marsh periwinkle snail Littoraria irrorata. Journal of Chemical Ecology 37:838-845.

Henry RP, McBride CJ, Williams AH (1993) Responses of the marsh periwinkle, Littoraria (Littorina) irrorata to temperature, salinity, and desiccation, and the potential physiological relationship to climbing behavior. Marine Behavioral Physiology 24:45-54.

Hughes R (2012) A neighboring plant species creates associational refuge for consumer and host. Ecology 93:1411-1420.

Jarrell ER, Kolker AS, Campbell C, Blum MJ (2016) Brackish marsh plant community responses to regional precipitation and relative sea-level rise. Wetlands 36:607-619.

Jeffrey SW, Welschmeyer NA (1997) Spectrophotometric and fluorometric equations in common use in oceanography. In: Jeffrey SW, Mantoura RFC, Wright SW (eds) Phytoplankton pigments in oceanography: Guidelines to modern methods. UNESCO, Paris, France, pp 597-615.

Johnson DS, Williams BL (2017) Sea level rise may increase extinction risk of a saltmarsh ontogenetic habitat specialist. Ecology and Evolution 7:7786-7795.

Kicklighter CE, Duca S, Jozwick AKS, Locke H, Hundley C, Hite B, Hannifin G (2018) Grazer deterrence and fungal inhibition by the invasive marsh grass Phragmites australis and the native sedge Bolboschoenus robustus in a mesohaline marsh. Chemoecology 28:163-172.

Lee SC, Silliman BR (2006) Competitive displacement of a detritivorous salt marsh snail. Journal of Experimental Marine Biology and Ecology 339:75-85.

Lewis DB, Eby LA (2002) Spatially heterogeneous refugia and predation risk in intertidal salt marshes. OIKOS 96:119-129.

Li F, Pennings SC (2018) Responses of tidal freshwater and brackish marsh macrophytes to pulses of saline water simulating sea level rise and reduced discharge. Wetlands 38:885-891.

Lin J (1989) Influence of location in a salt marsh on survivorship of ribbed mussels. Marine Ecology Progress Series 56:105-110. 
Lorenzen C (1967) Determination of chlorophyll and phaeopigments: spectrophotometric equations. Limnology and Oceanography 12:343-346.

McCann MJ, Able KW, Christian RR, Fodrie FJ, Jensen OP, Johnson JJ, López-Duarte PC, Martin CW, Olin JA, Polito MJ, Roberts BJ, Ziegler SL (2017) Key taxa in food web responses to stressors: the Deepwater Horizon oil spill. Frontiers in Ecology and the Environment 15:142-149.

McHugh JM, Dighton J (2004) Influence of mycorrhizal inoculation, inundation period, salinity, and phosphorus availability on the growth of two salt marsh grasses, Spartina alterniflora Lois. and Spartina cynosuroides (L.) Roth., in nursery systems. Restoration Ecology 12:533545.

Odum WE, Smith TJ III, Hoover JK, McIvor CC (1984) The ecology of tidal freshwater marshes of the United States east coast: a community profile. U.S. Fish and Wildlife Service, FWS/OBS-83/17. 177 pp.

Odum WE (1988) Comparative ecology of tidal freshwater and salt marshes. Annual Review of Ecology and Systematics 19:147-176.

Otte ML, Wilson G, Morris JT, Moran BM (2004) Dimethylsulphoniopropionate (DMSP) and related compounds in higher plants. Journal of Experimental Botany 55:1919-1925.

Penfound WT, Hathaway ES (1938) Plant communities in the marshlands of southeastern Louisiana. Ecological Monographs 8:1-56.

Pennings SC, Carefoot TH, Siska EL, Chase ME, Page TA (1998) Feeding preferences of a generalist salt-marsh crab: relative importance of multiple plant traits. Ecology 79:19681979.

Perry JE, Atkinson RB (1997) Plant diversity along a salinity gradient of four marshes on the York and Pamunkey Rivers in Virginia. Castanea 62:112-118.

R Core Team (2018) R: A Language and Environment for Statistical Computing. R Foundation for Statistical Computing, Vienna, Austria. https://www.R-project.org

Rietl AJ, Sorrentino MG, Roberts BJ (2018) Spatial distribution and morphological responses to predation in the salt marsh periwinkle. Ecosphere 9:e02316.

Schindler DE, Johnson BM, MacKay NA, Bouwes N, Kitchell JF (1994) Snail size-structured interactions and salt marsh predation gradients. Oecologia 97:49-61.

Shepard CC, Crain CM, Beck MW (2011) The protective role of coastal marshes: a systematic review and meta-analysis. PLOS ONE 6:e27374. 
Sieg RD, Wolfe K, Willey D, Ortiz-Santiago V, Kubanek J (2013) Chemical defenses against herbivores and fungi limit establishment of fungal farms on salt marsh angiosperms. Journal of Experimental Marine Biology and Ecology 446:122-130.

Silberhorn G (1992) Big Cordgrass, Giant Cordgrass Spartina cynosuroides (L.) Roth. Wetland Flora Technical Reports, Wetlands Program, Virginia Institute of Marine Science. Virginia Institute of Marine Science, College of William and Mary.

Silliman BR, Zieman JC (2001) Top-down control of Spartina alterniflora production by periwinkle grazing in a Virginia salt marsh. Ecology 82:2830-2845.

Silliman BR, Newell SY (2003) Fungal farming in a snail. Proceedings of the National Academy of Sciences of the United States of America 100:15643-15648.

Siska EL, Pennings SC, Buck TL, Hanisak MD (2002) Latitudinal variation in palatability of salt-marsh plants: which traits are responsible? Ecology 83:3369-3381.

Stevenson JC, Rooth JE, Kearney MS, Sundberg KL (2000) The health and long term stability of natural and restored marshes in the Chesapeake Bay. In: Weinstein MP, Kraeger DA (eds) Concepts and controversies in tidal marsh ecology, Kluwer Academic Publishing, Dordrecht, the Netherlands, pp 709-735.

Stribling JM (1997) The relative importance of sulfate availability in the growth of Spartina alterniflora and Spartina cynosuroides. Aquatic Botany 56:131-143.

Vaughn CC, Fisher FM (1992) Dispersion of the salt-marsh periwinkle Littoraria irrorata: effects of water level, size, and season. Estuaries 15:246-250.

VECOS Database. Virginia Estuarine and Coastal Observing System. Station TSK000.23 (Taskinas Creek). http://vecos.vims.edu/. Accessed July 16, 2019.

Warren JH (1985) Climbing as an avoidance behaviour in the salt marsh periwinkle, Littorina irrorata (Say). Journal of Experimental Marine Biology and Ecology 89:11-28.

Wass ML, Wright TD (1969) Coastal wetlands of Virginia. In: Applied Marine Science and Ocean Engineering, Number 10, Virginia Institute of Marine Science, College of William and Mary, Gloucester Point, $154 \mathrm{pp}$.

White SN, Alber M (2009) Drought-associated shifts in Spartina alterniflora and S. cynosuroides in the Altamaha River Estuary. Wetlands 29:215-224.

Zengel S, Weaver J, Pennings SC, Silliman B, Deis DR, Montague CL, Rutherford N, Nixon Z, Zimmerman AR (2017) Five years of Deepwater Horizon oil spill effects on marsh periwinkles Littoraria irrorata. Marine Ecology Progress Series 576:135-144. 


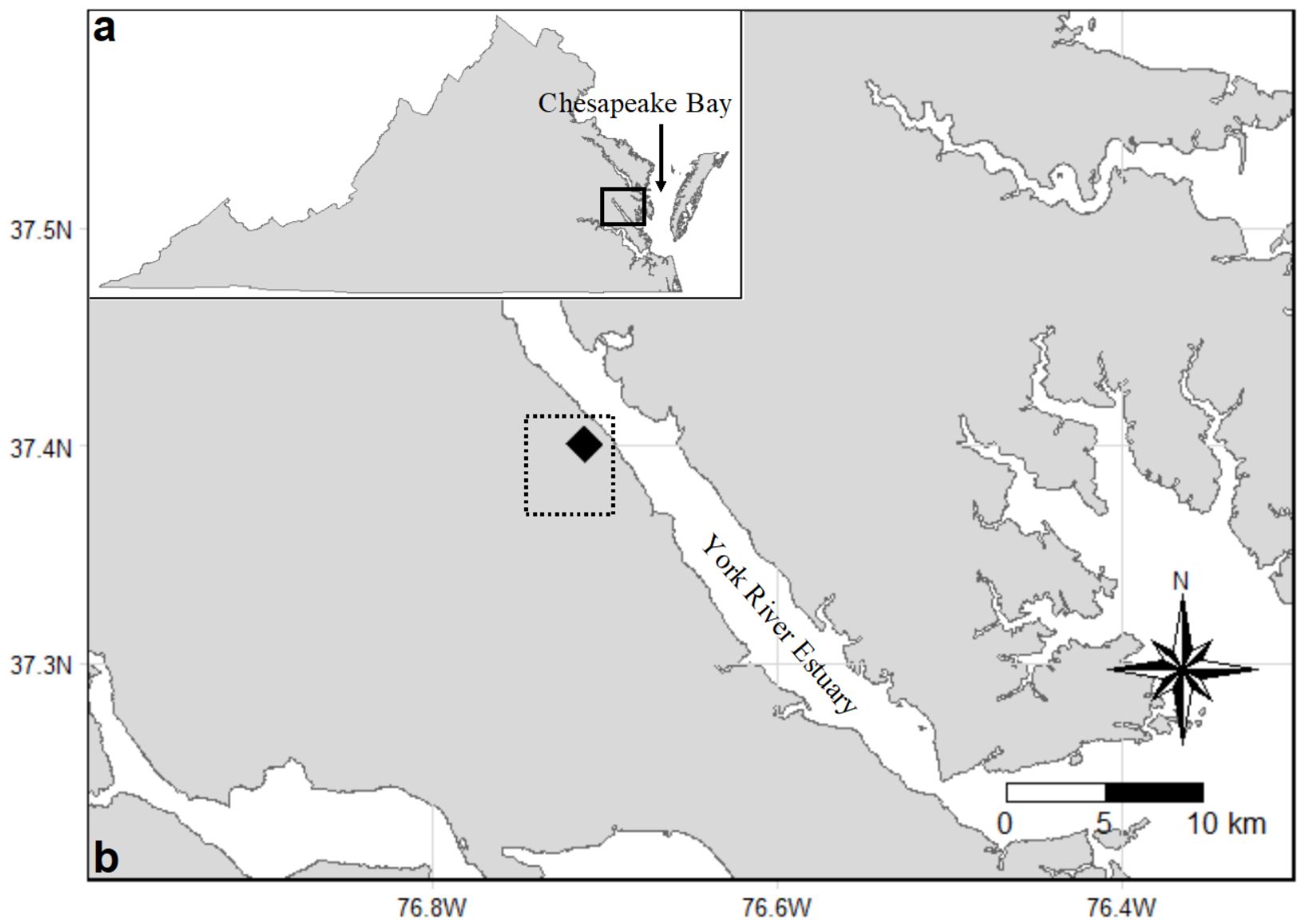

Fig. 1 a) Inset map of the state of Virginia. Boxed area indicates study region and arrow points to the Chesapeake Bay. b) Enlarged map of study region. Diamond is the location of Taskinas 


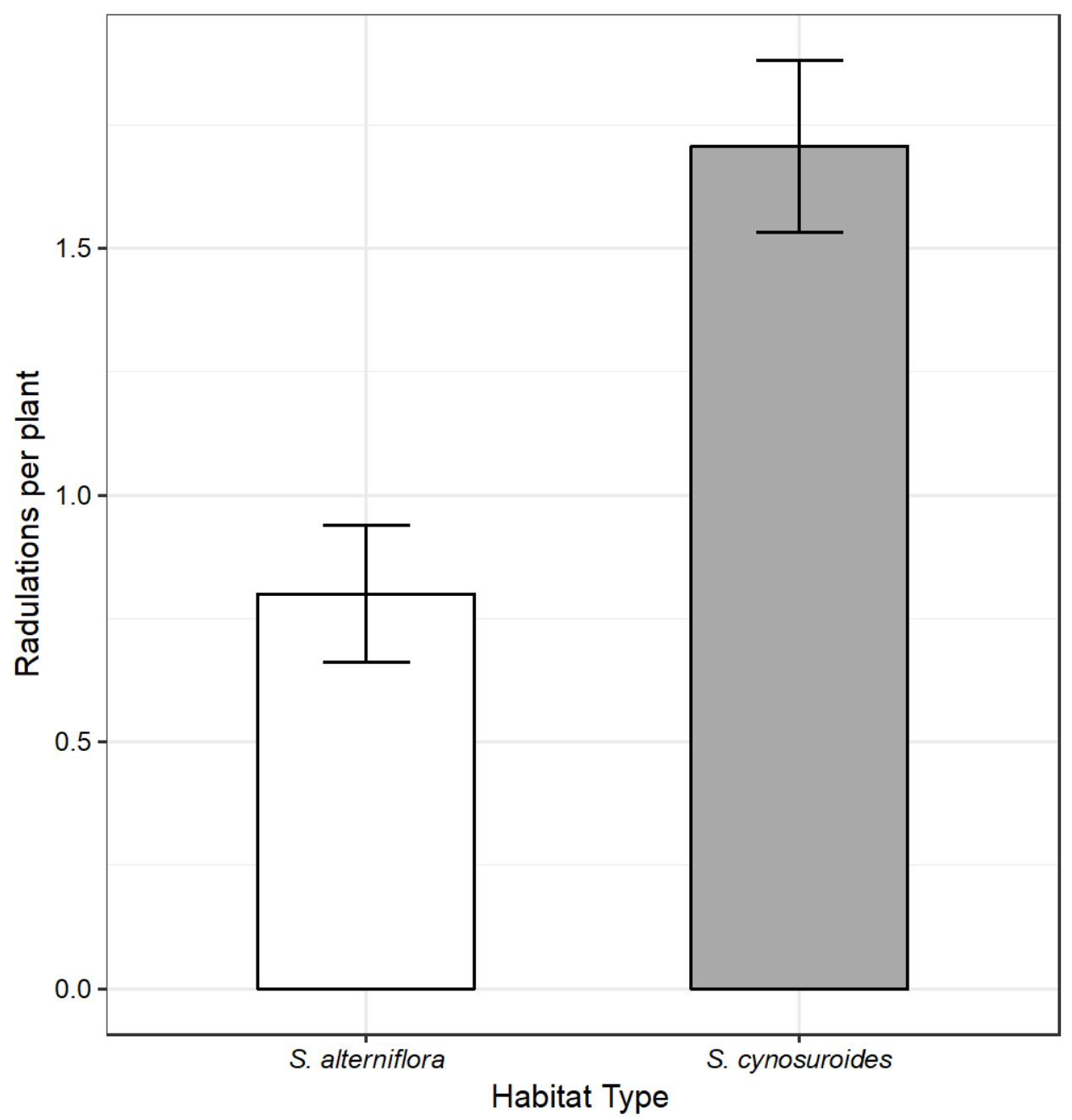

474

Fig. 2 Mean number of radulations per S. alterniflora and S. cynosuroides habitat. Error bars 476 477 represent standard error 

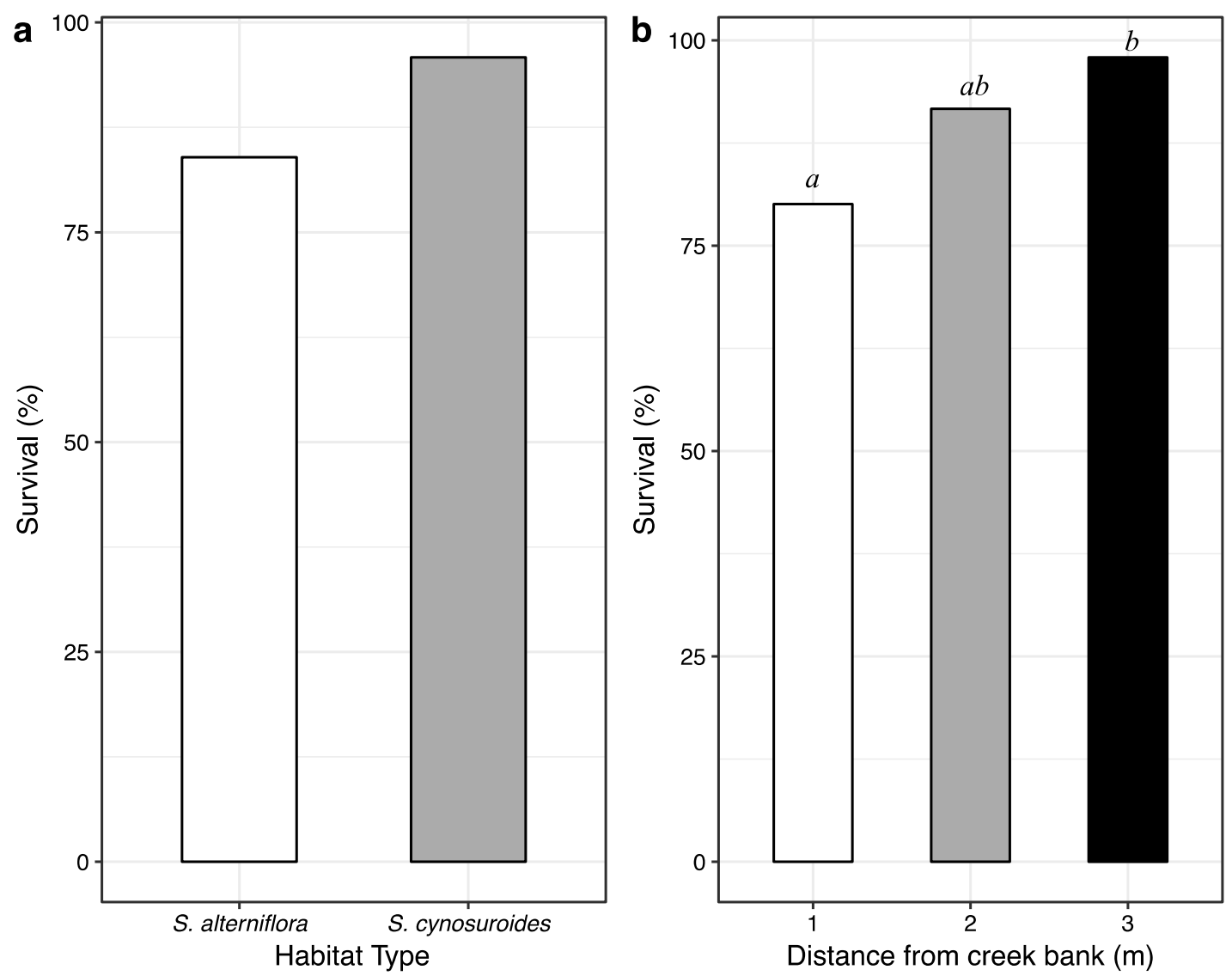

478
Fig. 3 Mean percent snail survival by a) S. alterniflora and S. cynosuroides habitat types and b) distance from the creek bank (habitats combined). The italicized letters above bars indicate the significant differences between levels 

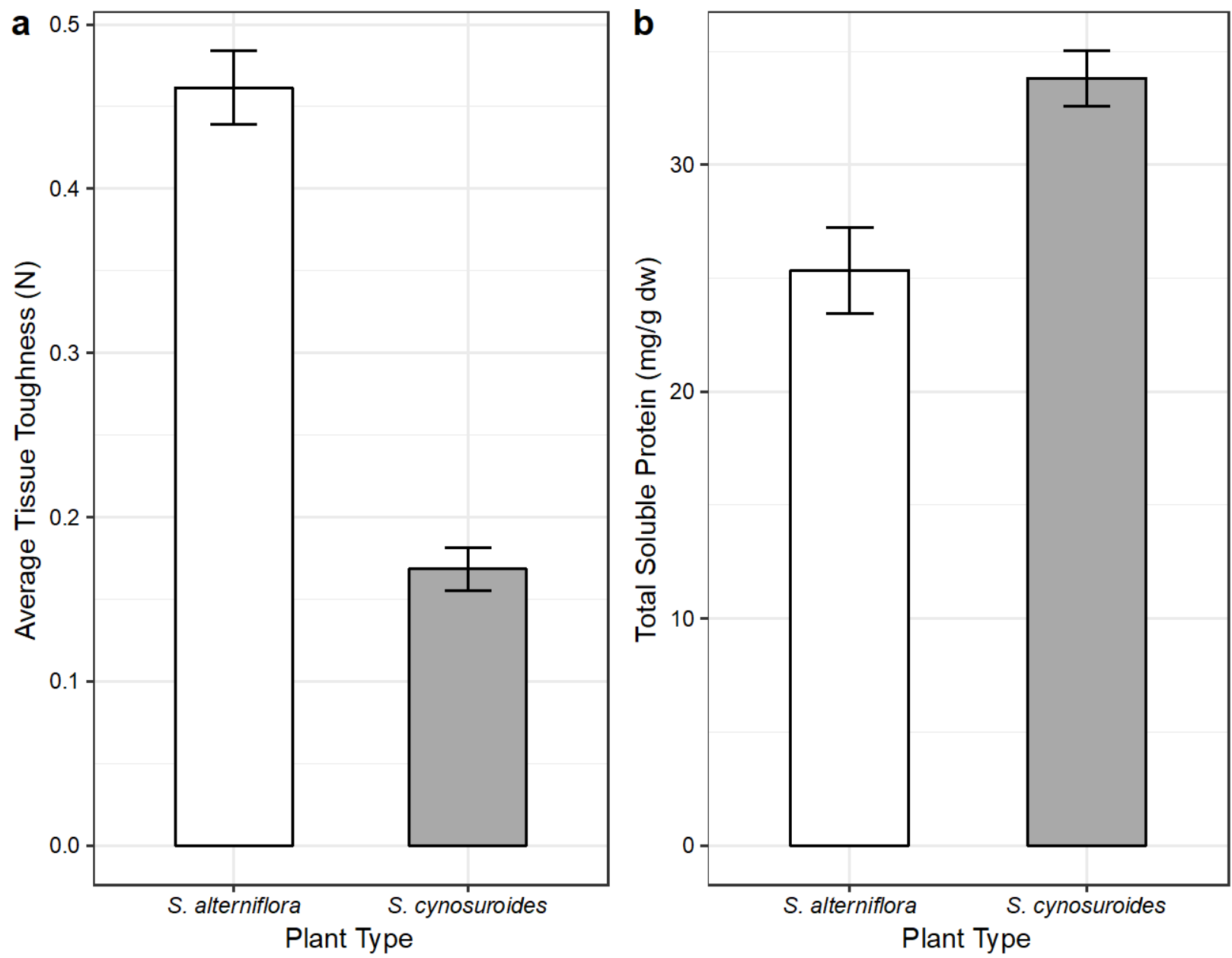

483

484

485

486

487

488
Fig. 4 Mean a) tissue toughness in Newtons and b) total soluble protein content in milligrams per gram dry weight for S. alterniflora and S. cynosuroides tissues. Error bars represent standard error 


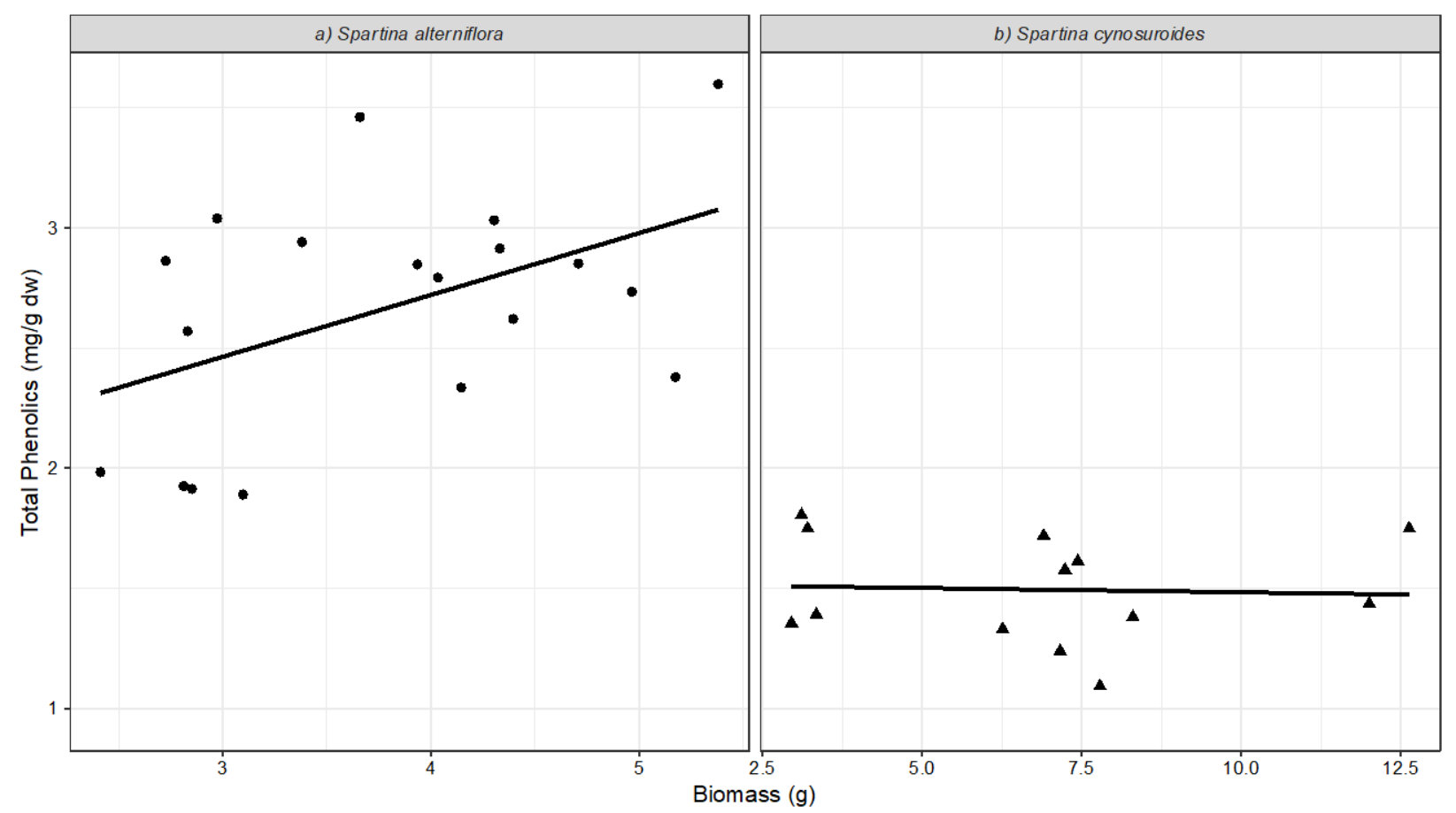

489

490

491

492

493

494

495

Fig. 5 Interaction of biomass and mean total phenolic concentration for a) S. alterniflora and b) S. cynosuroides. Trend lines represent smoothed, linear regression lines

\section{Electronic Supplementary Material Captions}




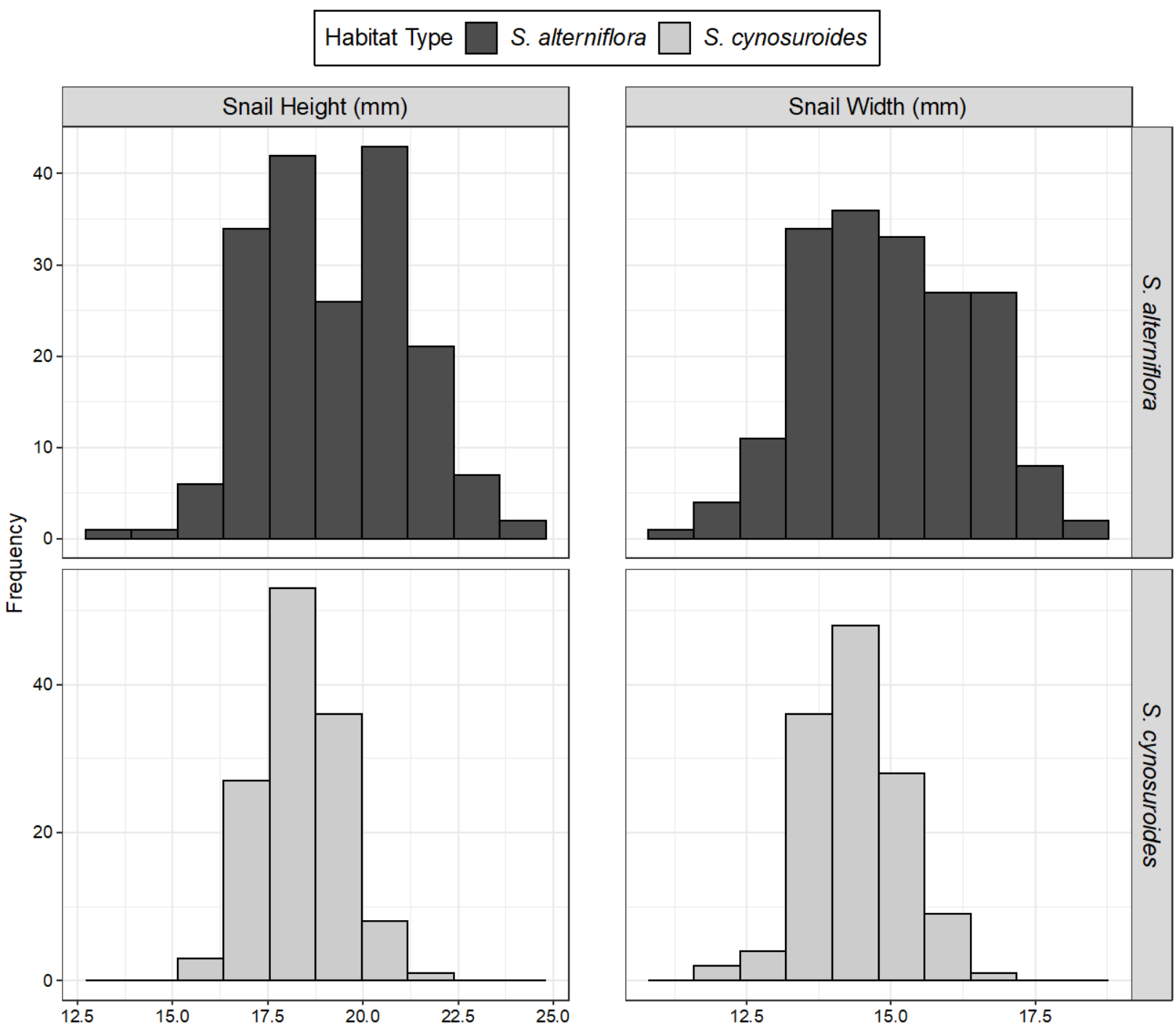

Online Resource 1 Size-frequency plots for shell height and width of L. irrorata found in a) $S$. alterniflora and b) S. cynosuroides habitats 

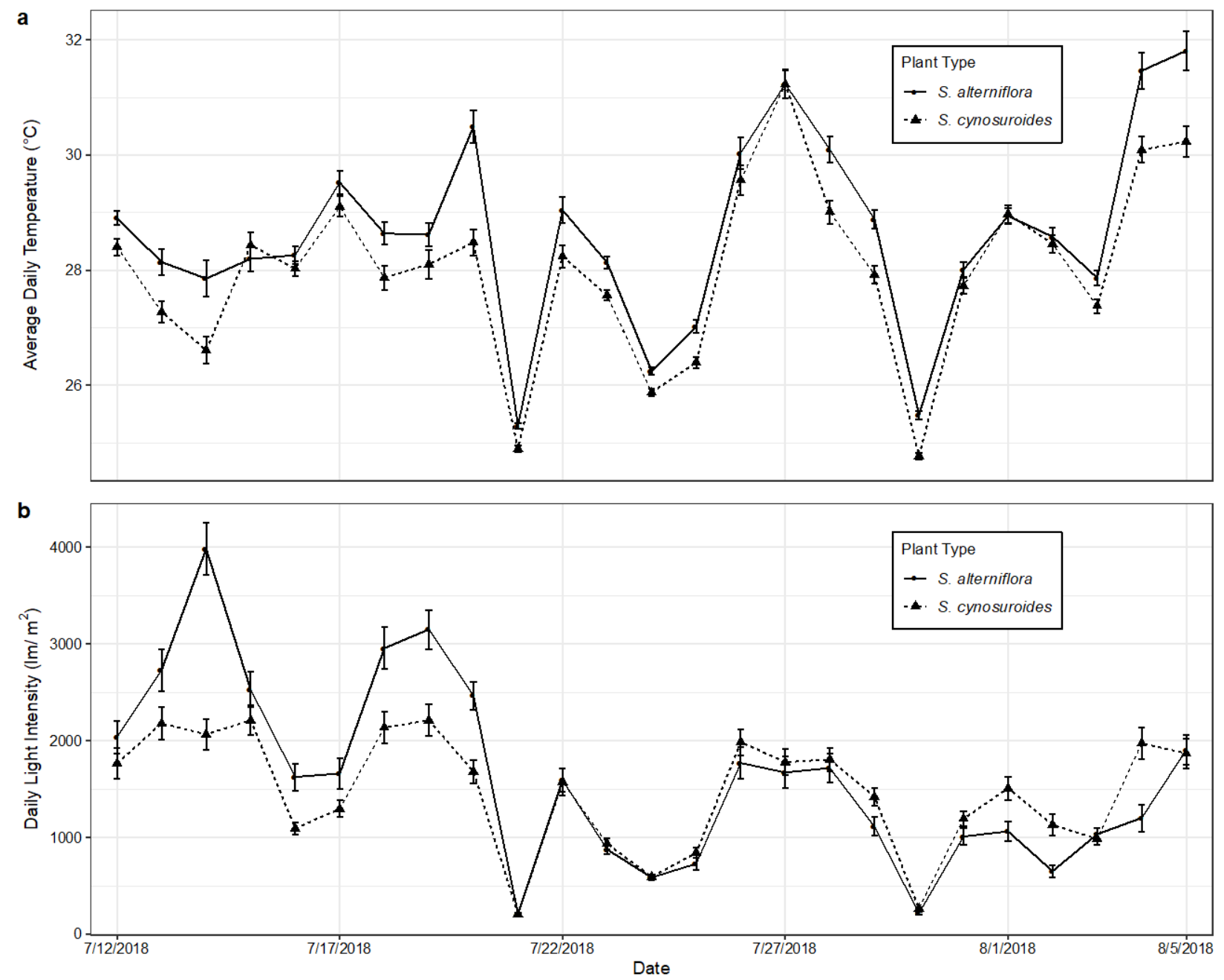

Online Resource 2 Mean a) daily temperature and b) daily light intensity in S. alterniflora and 502 S. cynosuroides habitats from July 12, 2018 through August 5, 2018. Error bars represent 503 standard error 